\title{
IMPORTANCE OF BRAND TRUST |ON CORPORATE SOCIAL RESPONSIBILITY
}

\author{
Dr. Ravi Kumar Goriparth, Dr. Merga Mekuria, Dr. Terefe Zeleke
}

\begin{abstract}
Corporate Social Responsibility (CSR) had a positive impact on consumer behavior, but even so little was known about these effects, research into trust specifically in a brand context is limited and the relationship between CSR and brand trust specifically needs to be identified. This paper tries to identify the relationship between CSR and brand trust, as well as the variables that best represent CSR. The findings showed that two components represented CSR which were legal \& employee and ethics \& economic and indicates there are different areas that both represent CSR and effect brand trust. In the multiple regression analysis, the legal \& employee component was the most influential component for the overall data and the socially responsible company as CSR explains a $22 \%$ variance on brand trust. The variance of brand trust that is explained by CSR in regards to the socially responsible company is greater than the variance explained by the less socially responsible company; the more socially responsible the company the larger percentage effect CSR has on brand trust. Overall this study explores the linkages between CSR and brand trust and provides a foundation for further research and identifies several important implications for the leaders of organizations to consider in terms of CSR investment and the effects on brands within their portfolio.

Key Words : CSR, Brand Trust, Relationship,
\end{abstract}

\section{INTRODUCTION}

CSR had a positive impact on consumer behavior, but even so little was known about the effects of CSR on the consumer. CSR aids the building of brand equity, especially when there is a consistent commitment to CSR efforts in the long term by an organization and in order to build this brand equity, consumers need to have faith in the company commitment to CSR, the purpose of CSR is to promote an image and enhance reputation, but trust helps maintain long term relationships with the consumer. CSR will influence corporate reputation positively, but does little to combat negative reputation in the long term and the reputation of an organization has involves an element of trust of behalf of the consumer. Moreover, consumer trust is a major component of brand loyalty, which reduces a consumers desire to switch products, organizations aspire to have loyal consumers, in order to reduce the costs associated with obtaining new clients as well increasing consumer fulfillment in terms of product offering. However, organizations have an issue in determining which CSR activities to participate in as if consumers suspect the company in participating in CSR for self-centered means, it creates negative perceptions and if a company could determine specific activities to be involved with in order to influence trust towards a brand, which fits in with the company image, can provide an important channel for creating positive consumer associations to foster customer loyalty.

This paper specifically tries to identify two areas of marketing, corporate social responsibility (CSR) and brand trust by conducting further exploratory research into the relationship between CSR and brand trust. Consumer trust is an asset, which companies can use to generate positive outcomes in every consumer relationship or transaction. Harnessing trust in a business-to-consumer relationship influences the attractiveness of a brand or company and possibly increases the positivity towards line extensions. CSR aids the building of brand equity, especially when there is a consistent commitment to CSR efforts in the long term by an organization. The purpose of CSR is to promote an image and enhance reputation, but trust helps maintain long term relationships with the consumer. To understand this one need to understand that what impact Corporate Social Responsibility has on Brand Trust and to know this there are two factors which represent CSR and brand trust. They are a combination of ethics and economic aspects and a combination of legal and employee aspects.

\section{OBJECTIVE OF THE STUDY}

The goal of an organization is to build strong brands in the market and foster long term relationships with consumers, the problem centers on businesses participating in CSR operations in order to influence brand while 
there has not been full investigation into the effects of CSR on the consumer, specifically consumer trust and by association consumer loyalty.

\section{LIMITATIONS OF STUDY}

1. Although the mall provided a location with a large number of groups with different ages, but this study didn't followed individual interpretation.

2. This study was conducted on members of the general public and conducted solely from a general public perspective.

3. The sample size that was used for data collection was 140 participants and the sample was smaller due to it being exploratory research, a larger sample size could be significant from a data analysis perspective, as a larger sample could identify relationships between components that have smaller significance.

\section{METHODOLOGY OF THE STUDY}

The methodology for this study is positivist, the study is limited to one shopping Centre, in Hyderabad which has a large sample and more likely to cover different groups. The data for this study was collected over a two week period and at different time intervals. Every third shopper entering or leaving the main entrances of the shopping complex is selected and approached to fill in a questionnaire. The sample was composed through quota sampling made up of 140 participants ranging from 21-50 years of age, with equal numbers of men and women. The questionnaire is composed of the company scenario with 70 of the participants were given the socially responsible scenario and 70 participants were given the non-socially responsible scenario. The data collected was based on five main constructs, brand trust (the dependent variables) and the elements of corporate social responsibility (the independent variables) being employees, legal, economic and ethical and a seven-point Likert scale was used to answer questions under each section of CSR. In the adapted 19 item CSR scale with two variables consisting of the company encouraging employee voluntary activities and non-governmental organizations.

A scenario is used as the basis for answering the survey, two fictitious companies manufacturing the same Delight brand, which is socially responsible, are used as a base scenario for the questionnaire. 70 participants will receive the socially responsible company (Amenity A) questionnaire and 70 will receive the non-socially responsible company (Amenity B) questionnaire. The Delight brand is described as a very successful line of body care products. The Delight line of body care products is made without any nasty chemicals, natural ingredients, with recyclable packaging. Delight is also described as not testing on animals. After the data was cleaned, it was tested to meet the assumptions of multivariate analysis. Secondly, a exploratory data analysis is conducted, which includes descriptive statistics and normality checking. A principal component analysis using VARIMAX rotation is used, finally, to examine the influence of CSR on brand trust, a multiple regression is performed on the finalized independent CSR components and the dependent brand trust component and the standardized regression coefficients will each be compared to see which CSR component had the greatest effect.

ANALYSIS

Table 1

Descriptive Statistics

\begin{tabular}{|c|c|c|c|c|c|}
\hline Construct & Variables & Mean & SD & Skewness & Kurtosis \\
\hline \multirow{6}{*}{ Brand Trust } & Delight will be interested in my satisfaction. & 5.20 & 1.39 & -0.78 & -0.21 \\
\hline & Delight will value me as a consumer of its products. & 5.11 & 1.31 & -0.32 & -0.83 \\
\hline & $\begin{array}{l}\text { Delight will offer me recommendations and advice on how } \\
\text { to make the most of its products. }\end{array}$ & 4.89 & 1.36 & -0.29 & -0.74 \\
\hline & $\begin{array}{l}\text { Delight will offer me a product with a consistent quality } \\
\text { level. }\end{array}$ & 4.84 & 1.21 & -0.62 & -0.01 \\
\hline & $\begin{array}{l}\text { Delight will help me solve any problem I may have with the } \\
\text { product. }\end{array}$ & 4.43 & 1.21 & -0.32 & -0.44 \\
\hline & Delight will offer me new products I may need & 4.40 & 1.16 & -0.01 & 0.19 \\
\hline \multirow[t]{5}{*}{ Employees } & $\begin{array}{l}\text { This company's policies encourage the employees to develop } \\
\text { their skills and careers. }\end{array}$ & 4.27 & 1.50 & -0.33 & -0.60 \\
\hline & $\begin{array}{l}\text { This company supports employees who want to acquire } \\
\text { additional education. }\end{array}$ & 4.19 & 1.50 & -0.30 & -0.50 \\
\hline & $\begin{array}{l}\text { This company has flexible policies to provide good work- } \\
\text { life balance for employees. }\end{array}$ & 4.19 & 1.38 & -0.19 & -0.25 \\
\hline & $\begin{array}{l}\text { The managerial decisions related with the employees are } \\
\text { usually fair. }\end{array}$ & 4.05 & 1.36 & -0.09 & -0.09 \\
\hline & The management of the company is primarily concerned & 3.85 & 1.50 & -0.00 & -0.69 \\
\hline
\end{tabular}




\begin{tabular}{|c|c|c|c|c|c|}
\hline & with employee's needs and wants. & & & & \\
\hline \multirow[t]{4}{*}{ Ethics } & Customer satisfaction is highly important for this company. & 5.18 & 1.47 & -0.69 & -0.02 \\
\hline & $\begin{array}{l}\text { This company provides full and accurate information about } \\
\text { its products to consumers }\end{array}$ & 4.83 & 1.66 & -0.37 & -0.91 \\
\hline & $\begin{array}{l}\text { This company emphasizes the importance of its social } \\
\text { responsibilities to society }\end{array}$ & 4.80 & 1.86 & -0.34 & -1.10 \\
\hline & $\begin{array}{l}\text { This company contributes to campaigns and projects that } \\
\text { promote the well-being of the society }\end{array}$ & 4.64 & 1.93 & -0.50 & -1.06 \\
\hline \multirow[t]{4}{*}{ Legal } & $\begin{array}{l}\text { This company complies with legal regulations safely and } \\
\text { promptly }\end{array}$ & 4.81 & 1.48 & -0.55 & -0.11 \\
\hline & $\begin{array}{l}\text { This company always pays its taxes on a regular and } \\
\text { continuing basis. }\end{array}$ & 4.50 & 1.49 & -0.55 & 0.09 \\
\hline & $\begin{array}{l}\text { This company would co-operate with its competitors on } \\
\text { social responsibility projects. }\end{array}$ & 4.46 & 1.70 & -0.40 & -0.57 \\
\hline & This company avoids unfair competition. & 4.25 & 1.46 & -0.09 & -0.32 \\
\hline \multirow[t]{4}{*}{ Economics } & $\begin{array}{l}\text { This company participates in activities which aim to protect } \\
\text { and improve the quality of the natural environment. }\end{array}$ & 4.83 & 2.02 & -0.58 & -0.95 \\
\hline & $\begin{array}{l}\text { This company makes investment to create a better life for } \\
\text { future generations. }\end{array}$ & 4.82 & 1.74 & -0.59 & -0.66 \\
\hline & $\begin{array}{l}\text { This company targets sustainable growth which considers } \\
\text { future generations. }\end{array}$ & 4.77 & 1.82 & -0.55 & -0.74 \\
\hline & $\begin{array}{l}\text { This company implements special programs to minimize its } \\
\text { negative impact on the natural environment. }\end{array}$ & 4.72 & 2.04 & -0.39 & 1.21 \\
\hline
\end{tabular}

Table 1 outlines the mean, S.D., skewness and kurtosis of brand trust and the CSR components of employee, economic, legal and ethics. Over the 25 items in 5 components, the means ranged from 3.85-5.20, the standard deviation rates are between 1.22 and 2.03., the brand trust variable mean ranged from 4.4-5.2. Amenity A and Amenity B had the same Delight brand which is a socially responsible brand where we can assume that the participants on average gave a slightly positive rating to brand trust, being in the 4.40-4.89 range, except for, interest in satisfaction as a consumer (5.20) and value as a consumer of products (5.11) which were positive. The lowest rated item described the offering of new products from the brand and the highest rated item, although only slightly positive, was the interest in satisfaction as a consumer. The employee items ranged in mean from 3.85-4.27. The item described as being concerned with employees developing their careers and skills had the highest mean at 4.27. The item which describes the management of the company being primarily concerned with employee needs and wants averaged at 3.85, which was the lowest score. The remaining items had a 61 range of 4.05-4.19; the items described work-life balance, managerial fairness and employees acquiring additional education. Ethics items ranged from a mean of 4.62-5.18; there was a slightly positive view of customer satisfaction being important for both companies with a mean of 5.18. The item that describes the company respecting consumer rights beyond the legal requirements had the lowest mean at 4.62. In the range of 4.64-4.83, the remaining items outlined the company providing accurate information, emphasizing the importance of societal responsibility and the company promoting well-being of society.

The legal items ranged in mean from 4.17-4.81. The item that asks whether the company complies with legal regulations safely and promptly had a greater positive reaction than the other items at 4.81 and the items describing paying taxes regularly, co-operating with competitors and avoiding unfair competition have means of $4.50,4.46$ and 4.25 respectively. The economic items ranged in mean from 4.72-4.82, which reflects positivity. The company participates in activities which aim to protect and improve the quality of the natural environment, was viewed as a slightly more positive item at 4.82 , the lowest mean was the item describing the company as implementing special programs to minimize the impact on the natural environment at 4.72 and the remaining items concerned investing in future generations with a mean of 4.82 and ensuring sustainable growth for future generations with a mean of 4.77. These findings suggest that employees are an important component to CSR and including employee variables in a CSR measurement scale is wise. This analysis shows that caring for the environment has a positive impact on financial performance, although there was mixed results, it can be suggested that both employee and economics items offer a greater representation of CSR.

\section{CSR MEAN COMPARISONS}

Table 2

T-Test Mean Comparisons for Corporate Social Responsibility 


\begin{tabular}{|c|c|c|c|}
\hline Elements & Corporate Social Responsibility & $\begin{array}{l}\text { Amenity } \\
\text { A }\end{array}$ & $\begin{array}{l}\text { Amenity } \\
\text { B }\end{array}$ \\
\hline \multirow{5}{*}{ 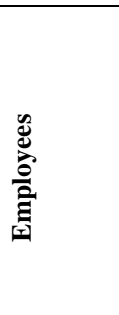 } & This company supports employees who want to acquire additional education. & 4.46 & 3.92 \\
\hline & This company's policies encourage the employees to develop their skills and careers & 4.36 & 4.18 \\
\hline & This company has flexible policies to provide good work-life balance for employees & 4.28 & 4.10 \\
\hline & The managerial decisions related with the employees are usually fair. & 4.22 & 3.88 \\
\hline & The management of the company is primarily concerned with employee's needs and wants. & 3.92 & 3.78 \\
\hline \multirow{5}{*}{ 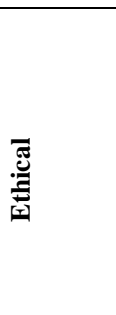 } & This company contributes to campaigns and projects that promote the well-being of the society & 5.66 & 3.62 \\
\hline & This company emphasizes the importance of its social responsibilities to society & 5.64 & 3.96 \\
\hline & This company provides full and accurate information about its products to consumers & 5.52 & 4.14 \\
\hline & Customer satisfaction is highly important for this company & 5.28 & 5.08 \\
\hline & This company respects consumer rights beyond the legal requirements & 5.02 & 4.22 \\
\hline \multirow{5}{*}{ 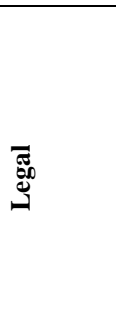 } & his company would co-operate with its competitors on social responsibility projects & 4.88 & 4.04 \\
\hline & This company complies with legal regulations safely and promptly & 4.86 & 4.76 \\
\hline & This company always pays its taxes on a regular and continuing basis & 4.38 & 4.62 \\
\hline & This company endeavors to create employment opportunities & 4.34 & 4.00 \\
\hline & This company avoids unfair competition & 4.32 & 4.18 \\
\hline \multirow{4}{*}{ 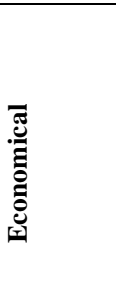 } & $\begin{array}{l}\text { This company participates in activities which aim to protect and improve the quality of the natural } \\
\text { environment }\end{array}$ & 5.8 & 3.86 \\
\hline & $\begin{array}{l}\text { This company implements special programs to minimize its negative impact on the natural } \\
\text { environment }\end{array}$ & 5.76 & 3.68 \\
\hline & This company targets sustainable growth which considers future generations & 5.68 & 3.86 \\
\hline & This company makes investment to create a better life for future generations & 5.6 & 4.04 \\
\hline
\end{tabular}

Mean comparisons for the data collected for both Amenity A and Amenity B were analyzed through a $t$ test. In the employee component, the item describing the company supporting employees that want to acquire additional education had the biggest mean variation between the two companies. The mean for the socially responsible company was 4.46 , in contrast to the non-socially responsible companies mean at 3.92. While supporting employees was the item with the highest mean for the socially responsible company, the highest mean for the non-socially responsible company was the item describing the organizations concerns with employee skills and career development. The lowest means for both companies was the item that describes the management of the company being concerned with employee needs and wants, at 3.92 and 3.78. The non-socially responsible company was rated lower on the ethics component than the socially responsible company. The highest rated item for the nonsocially responsible company was customer satisfaction being important to the company at 5.08, which is slightly positive. All items were rated 5.02 and higher for the socially responsible company, which means that company gave a positive impression in regards to ethics. The highest ranked item for the socially responsible company concerned participating in projects that helped the well-being of society at 5.66, which was also the lowest item for the non-socially responsible company at 3.62. The lowest rated item for the socially responsible company involved respecting consumer rights beyond the legal requirements at 5.02 which is still slightly positive.

In the legal component, the highest ranked item for the socially responsible company concerned the company participating with competitors on social responsibility projects at 4.88 . Again, this may be due to the fact the Amenity A scenario explicated stated the company participates in social projects. The item describing the 
company paying taxes regularly and on time had the highest mean for the non-socially responsible company at 4.62. The lowest ranked item for the socially responsible company was the company avoiding unfair competition at 4.32 , while the lowest mean for the non-socially responsible company was the company creating employment opportunities at 4.00. The legal component had the closest ranked means of all the CSR components.

The most noticeable mean differences between the socially responsible and non-socially responsible company is on the economics component, all the items under economics were viewed as a 5.60-5.80 for the socially responsible company, with participating in activities which aim to protect and improve the quality of the natural environment the highest mean at 5.80. In contrast, the non-socially responsible company has a mean range of 3.684.04. The item describing the company investing for future generations was the highest rated item for the nonsocially responsible company at 4.04 and was also the lowest ranked for the socially responsible company at 5.60, the lowest ranked item for the non-socially responsible company described participation in activities which aim to protect and improve the quality of the natural environment, at 3.68. The scenario for Amenity B describes the company as using both plastic and paper in packaging production and not sourcing from sustainable palm oil sources, which may have influenced the answer to the this question. The economics and ethics components had significant mean variations between the two companies. The non-socially responsible company was rated lower on the ethics component than the socially responsible company.

\section{Measurements of Reliability}

Table 3

Reliability Measure for All Interval-Scaled Variables

\begin{tabular}{|c|c|c|c|c|c|}
\hline \multirow{3}{*}{ 己气 } & \multirow[t]{3}{*}{ Variables } & \multirow{3}{*}{$\begin{array}{l}\text { Cornbach } \\
\text { a Alpha }\end{array}$} & \multicolumn{3}{|c|}{ Correlation } \\
\hline & & & \multirow{2}{*}{$\begin{array}{l}\text { Item } \\
\text { to total }\end{array}$} & \multicolumn{2}{|c|}{ Inter item } \\
\hline & & & & Min & Max \\
\hline \multirow{6}{*}{ 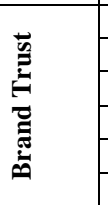 } & Delight will be interested in my satisfaction. & \multirow[t]{6}{*}{0.816} & .664 & \multirow[t]{6}{*}{0.297} & \multirow[t]{6}{*}{0.619} \\
\hline & Delight will value me as a consumer of its products. & & .657 & & \\
\hline & Delight will offer me recommendations and advice on how to make the most of its products. & & .560 & & \\
\hline & Delight will offer me a product with a consistent quality level. & & .558 & & \\
\hline & Delight will help me solve any problem I may have with the product. & & .528 & & \\
\hline & Delight will offer me new products I may need & & .510 & & \\
\hline \multirow{5}{*}{ 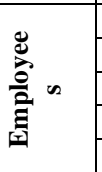 } & This company's policies encourage the employees to develop their skills and careers. & \multirow[t]{5}{*}{0.924} & .841 & \multirow[t]{5}{*}{0.636} & \multirow[t]{5}{*}{0.813} \\
\hline & This company supports employees who want to acquire additional education. & & .811 & & \\
\hline & This company has flexible policies to provide good work-life balance for employees. & & .795 & & \\
\hline & The managerial decisions related with the employees are usually fair. & & .795 & & \\
\hline & The management of the company is primarily concerned with employee's needs and wants. & & .770 & & \\
\hline \multirow{5}{*}{ 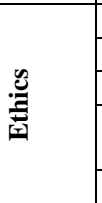 } & Customer satisfaction is highly important for this company. & \multirow[t]{5}{*}{0.899} & .833 & \multirow[t]{5}{*}{0.481} & \multirow[t]{5}{*}{0.88} \\
\hline & This company provides full and accurate information about its products to consumers & & .798 & & \\
\hline & This company emphasizes the importance of its social responsibilities to society & & .757 & & \\
\hline & $\begin{array}{l}\text { This company contributes to campaigns and projects that promote the well-being of the } \\
\text { society }\end{array}$ & & .744 & & \\
\hline & This company respects consumer rights beyond the legal requirements & & .642 & & \\
\hline \multirow{5}{*}{ 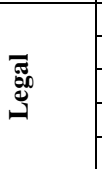 } & This company complies with legal regulations safely and promptly & \multirow[t]{5}{*}{0.875} & .801 & \multirow[t]{5}{*}{0.424} & \multirow[t]{5}{*}{0.757} \\
\hline & This company always pays its taxes on a regular and continuing basis. & & .760 & & \\
\hline & This company would co-operate with its competitors on social responsibility projects. & & .731 & & \\
\hline & This company avoids unfair competition. & & .629 & & \\
\hline & This company endeavors to create employment opportunities. & & .622 & & \\
\hline \multirow{4}{*}{ 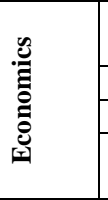 } & $\begin{array}{l}\text { This company participates in activities which aim to protect and improve the quality of the } \\
\text { natural environment. }\end{array}$ & \multirow[t]{4}{*}{0.958} & .919 & \multirow[t]{4}{*}{0.797} & \multirow[t]{4}{*}{0.924} \\
\hline & This company makes investment to create a better life for future generations. & & .905 & & \\
\hline & This company targets sustainable growth which considers future generations. & & .900 & & \\
\hline & $\begin{array}{l}\text { This company implements special programs to minimize its negative impact on the natural } \\
\text { environment. }\end{array}$ & & .876 & & \\
\hline
\end{tabular}

Reliability is measured by Cronbach 's Alpha and inter-item and item-to-total correlation. The item-to-total correlation represents the correlation of the item to the total item and the inter-item correlation outlines the correlations between the individual items. Item-to-total correlations should surpass 0.50 and inter-item correlations should be greater than 0.30 Cronbach's Alpha expresses the average of all split-half reliability coefficients which is a measure for the reliability and a Cronbach 's Alpha of 0.7 and above is considered acceptable, where a scale between 0 being no internal reliability and 1 being greatest internal reliability is present. From the table 3 each construct has a Cronbach's Alpha above 0.7, item-to-total correlations all exceed the recommended 0.5 level and the inter-item correlations are all past the passable level of 0.3 , although brand trust has a minimum inter-item correlation of 0.297 , it has been accepted as is close to the 0.3 mark and all the items are needed to test the different areas of brand trust. 
The first correlation matrix of CSR which was composed of employee, legal, economic and ethics constructs, resulted in a KMO MSA of 0.903 and a Barlett's level of .00 which is again significant with a KMO MSA of .840 and a Bartlett's value of .00. The correlation matrix for the brand trust construct had a KMO MSA output of 0.845 and a Bartlett's value of .00, which indicates it is appropriate for factor analysis. The rotation of the factor analysis for CSR was conducted. VARIMAX rotation was chosen on all 19 CSR variables resulted in crossloading on five of the variables, which resulted in them being deleted for the final factor analysis. The factors that were deleted were: Customer satisfaction is highly important for this company with a loading of 0.480 on factor 1 and 0.524 on factor 3 , the company respects consumer rights beyond the legal requirements with a loading of 0.544 on factor 1 and 0.545 on factor 3. This company avoids unfair competition with a loading of 0.495 on factor 2 and 0.589 on factor 3 , this company would co-operate with competitors on social responsibility projects with a loading of 0.606 on factor 1 and 0.595 on factor 3 and this company always pays its taxes on a regular and continuing basis with a loading of 0.488 on factor 2 and 0.727 on factor 3 .

\section{Extraction of Variables}

Table 4

Corporate Social Responsibility Dimensions and Variables

\begin{tabular}{|c|c|c|c|}
\hline \multirow[t]{2}{*}{ Variable } & \multicolumn{2}{|l|}{ Component } & \multirow[t]{2}{*}{ Communalities } \\
\hline & $\begin{array}{l}\text { Ethics \& } \\
\text { Economic }\end{array}$ & $\begin{array}{l}\text { Legal } \\
\text { \& Employee }\end{array}$ & \\
\hline This company supports employees who want to acquire additional education & & .849 & .78 \\
\hline This company's policies encourage the employees to develop their skills and careers & & .855 & .76 \\
\hline $\begin{array}{l}\text { The management of the company is primarily concerned with employees needs and } \\
\text { wants }\end{array}$ & & .826 & .74 \\
\hline This company has flexible policies to provide good work-life balance for employees & & .829 & .71 \\
\hline The managerial decisions related with the employees is usually fair & & .859 & .77 \\
\hline $\begin{array}{l}\text { This company provides full and accurate information about its products to } \\
\text { consumers }\end{array}$ & .749 & & .68 \\
\hline This company emphasizes the importance of its social responsibilities to society & .822 & & .76 \\
\hline $\begin{array}{l}\text { This company contributes to campaigns and projects that promote the well-being of } \\
\text { the society }\end{array}$ & .855 & & .81 \\
\hline This company endeavors to create employment opportunities & & .632 & .54 \\
\hline This company complies with legal regulations safely and promptly & & .646 & .51 \\
\hline $\begin{array}{l}\text { This company implements special programs to minimize its negative impact on the } \\
\text { natural environment }\end{array}$ & .893 & & .84 \\
\hline $\begin{array}{l}\text { This company participates in activities which aim to protect and improve the quality } \\
\text { of the natural environment }\end{array}$ & .919 & & .88 \\
\hline This company targets sustainable growth which considers future generations & .916 & & .87 \\
\hline This company makes investment to create a better life for future generations & .870 & & .83 \\
\hline Eigenvalues & 8.001 & \multicolumn{2}{|l|}{2.477} \\
\hline Cumulative \% Variance & $40.40 \%$ & \multicolumn{2}{|l|}{$\mathbf{7 4 . 8 4 \%}$} \\
\hline \multicolumn{4}{|c|}{$\begin{array}{l}\text { From table } 4 \text {, component } 1 \text { had an eigenvalue of } 8.001 \text { which is above the recommended level of } 1 \\
\text { had a percentage variance explanation of } 40.4 \% \text {, which although below the recommended } 60 \% \text {, a perc } \\
\text { variance has no absolute percentage cut off. Component } 2 \text { had an eigenvalue of } 2.477 \text { which is again ov } \\
\text { recommended } 1.0 \text { level. There was a percentage variance explanation of } 74.8 \% \text {, which is above the recomm } \\
60 \% \text { level. Also, the scree plot plotted this component as the second most important and above the inflection } \\
\text { which makes it retainable. The communality levels for the CSR variables are all above } 0.5 \text {, they are all sign } \\
\text { as well as loading cleanly on component } 1 \text { and component } 2 \text {. } \\
\text { Brand Trust }\end{array}$} \\
\hline \multirow{2}{*}{\multicolumn{2}{|c|}{ Variable }} & Component & \multirow{2}{*}{$\begin{array}{l}\text { Comm } \\
\text { unalities }\end{array}$} \\
\hline & & Brand Trust & \\
\hline \multicolumn{2}{|l|}{ Delight will offer me a product with a consistent quality level } & .659 & .43 \\
\hline \multicolumn{2}{|l|}{ Delight will help me solve any problem I may have with the product } & .705 & .59 \\
\hline Delight will offer me new products I may need & & .675 & .46 \\
\hline Delight will be interested in my satisfaction & & .788 & .62 \\
\hline Delight will value me as a consumer of its products & & .293 & .63 \\
\hline Delight will offer me recommendations and advice on how to make the most of its pr & ducts & .704 & .50 \\
\hline Eigenvalues & & 3.13 & \\
\hline Cumulative \% Variance & & 52.26 & \\
\hline
\end{tabular}


The brand trust variables all loaded on one component in table 5, with an eigenvalue of 3.13 and a percentage variance of $52.26 \%$. The communality on the variables of constant quality level and offering new products are below the 0.5 significant level. However, there is strong significant loading onto the one brand trust component and the communality levels are close to 0.5 , which means the component is retained.

Regression coefficients

Table 6

Regression Output

\begin{tabular}{|c|c|c|c|c|c|c|c|}
\hline \multirow[t]{2}{*}{ Tests } & & \multirow[b]{2}{*}{$\begin{array}{l}\text { Ethics \& } \\
\text { Economic }\end{array}$} & \multirow[b]{2}{*}{$\begin{array}{l}\text { Legal \& } \\
\text { Employee }\end{array}$} & \multicolumn{2}{|c|}{ Brand Trust Amenity A } & \multicolumn{2}{|c|}{ Brand Trust Amenity B } \\
\hline & & & & $\begin{array}{l}\text { Ethics } \\
\text { Economic }\end{array}$ & $\begin{array}{l}\text { Legal \& } \\
\text { Employee }\end{array}$ & $\begin{array}{l}\text { Ethics \& } \\
\text { Economic }\end{array}$ & $\begin{array}{l}\text { Legal \& } \\
\text { Employee }\end{array}$ \\
\hline \multirow{3}{*}{$\begin{array}{l}\text { Standardized } \\
\text { Coefficients }\end{array}$} & Beta & 0.221 & 0.432 & 0.472 & 0.581 & 0.300 & 0.241 \\
\hline & t. & 2.487 & 4.865 & 4.524 & 5.576 & 2.2216 & 1.779 \\
\hline & Sig & 0.015 & 0.000 & 0.000 & 0.000 & 0.032 & 0.082 \\
\hline \multicolumn{2}{|l|}{$\mathbf{R 2}$} & \multicolumn{2}{|c|}{$0.235=23.5 \%$} & \multicolumn{2}{|l|}{$0.496=49.6 \%$} & \multicolumn{2}{|l|}{$0.178=17.8 \%$} \\
\hline \multicolumn{2}{|l|}{ Adjusted R2 } & \multicolumn{2}{|c|}{$0.220=22 \%$} & \multicolumn{2}{|l|}{$0.475=47.5 \%$} & \multicolumn{2}{|l|}{$0.43=43 \%$} \\
\hline \multicolumn{2}{|l|}{ p value } & \multicolumn{2}{|l|}{0.000} & \multicolumn{2}{|l|}{0.000} & \multicolumn{2}{|l|}{0.010} \\
\hline
\end{tabular}

\section{REGRESSION COEFFICIENTS}

The significance level is under the desired 0.05 level for both the independent factors, which means that the confidence level is above the $95 \%$ mark. The $t$. value is above the +1.96 mark, which determines it has significant effect on the dependent variable. The beta values demonstrate which variable has the most variation effect in brand trust. The 0.432 beta value of legal \& employee shows that this variable has much greater effect in the variation of brand trust for CSR than ethics \& economics. The coefficient of determination indicates the percentage of total variance of brand trust that is explained by CSR, in this case it is $22 \%$. The regression coefficient for Amenity A is significant at the 0.05 level for both the independent variables. Both independent variables that represent CSR are suitable to predict variance in the dependent variable of brand trust. The beta values demonstrate which variable has the most effect on brand trust. The legal \& employee component had a greater effect on Amenity A with 0.581 beta value.

The percentage of total variance of brand trust that is explained by CSR in regards to Amenity A, the socially responsible company, is $47.5 \%$. This is significantly higher that the variance explained in brand trust for Amenity B. For Amenity B only the ethics \& economics variable was significant as the $t$. value was above the +1.96 mark the legal \& employee item on Amenity B is only marginally significant at $\mathrm{p}<0.10$, which means ethics \& economics is the only item to predict on the brand trust of Amenity B. In contrast to Amenity A, the ethics \& economics variable has a slightly greater effect at 0.300 for Amenity B. Amenity B had a significantly lower variance explanation for brand trust at $14.3 \%$. These findings are interesting, as it could be interpreted as the more socially responsible the company is the greater effect CSR will have on variance in brand trust. The individual socially responsible and nonsocially responsible regression analysis results are examined in table 4.7 and table 4.8. Tolerance and VIF (Variance Inflation Factor) both measure multicollinearity. The VIF is above 0.1 for both Amenity A and Amenity B in this instance, being 1.14 and 1.046 respectively, which equals a tolerance level of over one and that means there is no collinearity. The tolerance level is also below 10, which is considered acceptable.

\section{CONCLUSION}

This study empirically measured CSR using a multivariate method composed of a factor analysis, independent $t$-test and multiple regressions. This study concludes that CSR has a larger effect on brand trust for the socially responsible organization and the results suggest CSR provides an opportunity for companies to develop stakeholder relationships, while companies already participating in CSR should communicate CSR effectively in order to receive the benefits. Further investigation into the impact of CSR on different consumer characteristics is imperative for developing research into consumer and brand relationships. Despite the limitations, this study has provided a foundation for further investigation into both corporate social responsibility and brand trust while examining the connections between the two concepts.

\section{REFERENCES}

1. Ahluwalia, R. \&Kaikati, A.M. (2009). Traveling the paths to brand loyalty. In B. Loken, R. Ahluwalia \& M.J. Houston (Eds.), Brands \& Brand Management: Contemporary Research Perspectives (pp. 91-106). London, England: Psychology

2. Angus-Leppan, T., Metcalf, L.A. \& Benn, S. (2010). Leadership styles and CSR practice: An examination of sense making, institutional drivers and CSR leadership. Journal of Business Ethics, 93, 189-213. doi: 10.1007/s10551-009-0221-y 
3. Arvidsson, S. (2010). Communication of corporate social responsibility: A study of the views of management teams in large companies. Journal of Business Ethics, 96, 339-54. doi: 10.1007/s10551-010-0469-2 97

4. Bansal, P. and Roth, K. (2000). Why companies go green: A model of ecological responsiveness. Academy of Management Journal, 43(4), 717-36.

5. Bhattacharya, C. B., \& Sen, S. (2004). Doing better at doing good: When, why, and how consumers to corporate social initiatives. California Management Review, 47(1), 9-24.

6. Biloslavo, R. \& Trnavcevic, A. (2009). Websites as tools of communication of a -greenll company. Managerial Decision, 47(7), 1158-73. doi: $10.1108 / 00251740910978359$

7. Brilius, P. (2010). Dynamic model of dependencies between economic crisis and corporate social responsibility contribution to sustainable development. Economics and Management, 15, 422-29.

8. Carrigan, M., \& Attalla, A. (2001). The myth of the ethical consumer-do ethics matter in purchase behaviour? Journal of Consumer Marketing, 18(7), 560-77. doi: 10.1108/07363760110410263

9. Castaldo, S., Perrini, F., Misani, N., \& Tencati, A. (2009). The missing link between corporate social responsibility and consumer trust: The case of fair trade products. Journal of Business Ethics, 84(1), 1-15. doi: 10.1007/s10551-008-9669-4

10. Chaudhuri, A. \& Holbrook, M.B. (2001). The chain of effect from brand trust and brand effect to brand performance: The role of brand loyalty. Journal of Marketing, 65, 81-93. doi: 10.1509/jmkg.65.2.81.18255

11. Cruz, L.B. \& Pedrozo, E.A. (2009). Corporate social responsibility and green management: Relation between headquarter and subsidiary in multinational corporations. Managerial Decision, 47(7), 1174-99. doi: 10.1108/00251740910978368 100

12. Delgado-Ballester, E. \& Munuera-Aleman, J.L. (2005). Does brand trust matter to brand equity? Journal of Product \& Brand Management, 14(3), 187-96. doi: 10.1108/10610420510601058

13. Du, S., Bhattacharya, C. B., \& Sen, S. (2007). Reaping relational rewards from corporate social responsibility: The role of competitive positioning. International Journal of Research in Marketing, 24(3), 224-241. doi:10.1016/j.ijresmar.2007.01.001

14. Dunn, M. \& Davis, S. (2004). Creating the brand-driven business: It's the CEO who must lead the way. Handbook of Business Strategy, 5, 243-48. doi: 10.1108/10775730410494143

15. Foote, J., Gaffney, N. \& Evans, J.R. (2010). Corporate social responsibility: Implications for performance excellence. Total Quality Management, 21(8), 799-812. doi: 10.1080/14783363.2010.487660

16. Frederiksen, C.S. (2010). The relation between policies concerning corporate social responsibility and philosophical moral theoriesAn empirical investigation. Journal of Business Ethics, 93(3), 357-71. doi: 10.1007/s10551-009-0226-6

17. Geva, A. (2008). Three models of corporate social responsibility: Interrelationships between theory, research and practice. Business and society review, 113(1), 1-41. doi: 10.1111/j.1467-8594.2008.00311.x

18. Gurhan-Canli, Z. \& Fries, A. (2009). Branding and corporate social responsibility (CSR). In B. Loken, R. Ahluwalia \& M.J. Houston (Eds.), Brands \& Brand Management: Contemporary Research Perspectives (pp. 91-106). London, U.K: Psychology Press. 103

19. Hair, J.F., Black, W.C., Babin, B.J. \& Anderson, R.E. (2010) Multivariate data Analysis: A global perspective (7th ed.). New Jersey, NJ: Pearson Education Inc.

20. Keller, K.L. (2008). Strategic Brand Management (3rd ed.). New Jersey, NJ: Pearson Education Inc.

21. Kim, H.R., Moonkyu, L., Lee, H.T. \& Kim, M.N. (2010). Corporate social responsibility and employee-company identification. Journal of Business Ethics, 95, 557-69. doi: 10.1007/s10551-010-0440-2 104

22. Kim, Y. \& Kim, S.Y. (2010). The influence of cultural values on perceptions of corporate social responsibility: Application of Hofstede's dimensions to Korean public relations practitioners. Journal of Business Ethics, 91, 485-500. doi: 10.1007/s10551-0090095-z

23. Lai, C.H., Chiu, C.J., Yang, C.F. \& Pai, D.C. (2010). The effects of corporate social responsibility on brand performance: The mediating effect of industrial brand equity and corporate reputation. Journal of Business Ethics, 95, 457-69. doi: 10.1007/s10551-0100433-1

24. Marin, L., \& Ruiz, S. (2007). - I need you too!ll Corporate identity attractiveness for consumers and the role of social responsibility. Journal of Business Ethics, 71, 245-260. doi: 10.1007/s10551-006-9137-y

25. Murillo, D. \& Lorenzo, J.M. (2006). SMEs and CSR: An approach to CSR in their own words. Journal of Business Ethics, 67, 227-40. doi: 10.1007/s10551-006-9181-7

26. Peloza, J. \& Shang, J. (2011) How can corporate social responsibility activities create value for stakeholders? A systematic review. Journal of the Academy of Marketing Science, 39, 117-35. doi: 10.1007/s11747-010-0213-6

27. Pivato, S., Misani, N. \& Tencati, A. (2008). The impact of corporate social responsibility on consumer trust: The case of organic food. Business Ethics: A European Review, 17(1), 3-10. doi: 10.1111/j.1467-8608.2008.00515.x

28. Porter, M.E. \& Kramer, M.R. (2002). The competitive advantage of corporate philanthropy. Harvard Business Review, 80, 12, 1-15.

29. Quairel-Lanoizele'e, F. (2011). Are competition and corporate social responsibility compatible? The myth of sustainable competitive advantage. Society and Business Review, 6(1), 77-98. doi: 10.1108/17465681111105850

30. Russo, A. \& Perrini, F. (2010). Investigating stakeholder theory and social capital: CSR in large firms and SMEs. Journal of Business Ethics, 91, 207-21. doi: 10.1007/s10551-009-0079-z

31. Sen, S. \& Bhattacharya, C.B. (2001). Does doing good always lead to doing better? Consumer reactions to corporate social responsibility. Journal of Marketing Research, 38, 225-43. doi: 10.1509/jmkr.38.2.225.18838

32. Sen, S., Bhattacharya, C.B. \& Korschun (2006). The role of corporate social responsibility in strengthening multiple stakeholder relationships: A field experiment. Journal of the Academy of Marketing Science, 34(2), 158-66. doi: 10.1177/0092070305284978

33. Sharp, Z. \& Zaidman, N. (2010). Strategization of CSR. Journal of Business Ethics, 93(1), 51-71. doi: 10.1007/s10551-009-0181-2

34. Stegaroiu, I. \& Baranga, L. (2010). Corporate social responsibility. Metalurgia International, 15(6),148-52.

35. Turker, D. (2009). How corporate social responsibility influences organizational commitment. Journal of Business Ethics, 89, 189204. doi: 10.1007/s10551-008-9993-8

36. Wagner, M. (2010).Corporate social performance and innovation with high social benefits: A quantitative analysis. Journal of Business Ethics , 94, 581-94.

37. Walton, S.B. \& Rawlins, B. (2010). Do the right thing: Measuring the effectiveness of corporate social responsibility. Public Relations Tactics, 17(7), 10-11

38. Yu, V., Ting, H.I. \& Wu, Y.C.J. (2009). Assessing the greenness effort for European firms: A resource efficiency perspective. Managerial Decision, 47(7), 1065-80. doi: 10.1108/00251740910978304 